\title{
ANALISIS PARAMETER FISIS LEMPUNG DALAM PENENTUAN DAYA DUKUNG TANAH (STUDI KASUS: KECAMATAN MANYAR, KABUPATEN GRESIK)
}

\author{
Ahmad Widodo, Widya Utama, M. Singgih Purwanto, dan M. Haris Miftakhul Fajar \\ Departemen Teknik Geofisika, Fakultas Teknik Sipil, Perencanaan, dan Kebumian, \\ Institut Teknologi Sepuluh Nopember (ITS) \\ e-mail: ahmadwidodo02@gmail.com
}

\begin{abstract}
Abstrak. Kawasan reklamasi di Kecamatan Manyar, Gresik merupakan daerah dengan kondisi tanahnya yang didominasi oleh tanah lempung. Sebelum dilakukan pembangunan dan pembebanan, perlu dilakukan investigasi untuk mendapatkan daya dukung tanah lempung tersebut. Tujuan dari penelitian ini ialah untuk mendapatkan karakter fisis lempung di lokasi penelitian, dan mendapatkan daya dukung optimum dari model tanah lempung dan tanah timbunan. Penelitian dilakukan dengan melakukan pemodelan tanah dan pemberian beban permukaan. Sehingga didapatkan nilai penurunan yang kemudian digunakan untuk penentuan nilai daya dukung. Penelitian ini menggunakan sampel lempung dari lapangan untuk dilakukan pengukuran sifat fisis secara langsung. Didapatkan hasil densitas 1,448 gr/cm3, porositas 70,046 \%, specific gravity 2,565 dan kohesi $5,238 \mathrm{kN} / \mathrm{m}^{2}$. Hasil analisis hubungan antar parameter didapatkan bahwa antara specific gravity - porositas, kohesi - specific gravity dan kohesi - porositas menujukkan adanya hubungan parameter yang kuat. Sedangkan parameter yang tidak menunjukkan adanya korelasi ialah antara porositas - densitas, specific gravity - densitas dan kohesi - densitas. Dari 4 model tanah yang dimodelkan didapatkan hasil daya dukung optimum untuk model 1 sebesar $35 \mathrm{kN} / \mathrm{m}^{2}$, model 2 sebesar $40 \mathrm{kN} / \mathrm{m}^{2}$, model 3 sebesar $43 \mathrm{kN} / \mathrm{m}^{2}$, dan model 4 sebesar $47 \mathrm{kN} / \mathrm{m}^{2}$.

Kata Kunci: Daya Dukung Tanah; Lempung; Parameter Fisis; Penurunan Tanah
\end{abstract}

Abstract. Reclamation area in Manyar Subdistrict, Gresik is an area with base soil dominated by clay. Before construction and loading carried out, an investigation is needed to obtain the bearing capacity of clay. The purpose of this study was to obtain physical characteristics of clay at the site, and obtain the bearing capacity of soil and embankments. then performed loading modeling with clay models and embankments. This study was do with made soil modeling and giving surface loads. So we get values of settlement which is then used for determining the bearing capacity. This study used clay samples from the field to measure physical properties directly. Obtained density results is $1,448 \mathrm{gr} / \mathrm{cm}^{3}$, porosity is $70,046 \%$, specific gravity is 2,565 and cohesion is $5,238 \mathrm{kN} / \mathrm{m}^{2}$. The results of analysis of the correlation between parameters found that between specific gravity - porosity, cohesion - specific gravity and cohesion porosity shows a strong correlation. While the parameters that do not indicate a correlation are between porosity - density, specific gravity - density, and cohesion - density. From the 4 soil models the optimum bearing capacity for model 1 is $35 \mathrm{kN} / \mathrm{m}^{2}$, model 2 is $40 \mathrm{kN} / \mathrm{m}^{2}$, model 3 is $43 \mathrm{kN} / \mathrm{m}^{2}$, and model 4 is 47 $k N / m^{2}$.

Keywords: Bearing Capacity of Soils; Clay; Physical Parameters; Settlement

\section{PENDAHULUAN}

Daerah pembangunan industri di kawasan industri Java Integrated Indutrial and Port Estate (JIIPE) merupakan wilayah yang masih berada dalam tahap awal rencana pembangunan. Kawasan ini berada di Kecamatan Manyar, Kabupaten Gresik yang memiliki kondisi geologi berupa endapan aluvium yang didominasi oleh lempung (Sukardi, 1992) . Geologi daerah penelitian dapat dilihat pada gambar 1 . Daerah ini berada di daerah lepas pantai, yang berbatasan langsung dengan Laut Selat Madura. Endapan sedimen yang berada disekitar Selat Madura dihasilkan oleh endapan dari daerah pantai yang masuk ke bagian daratan hingga $\pm 5 \mathrm{~km}$. Perencanaan pondasi sangat diperlukan sebelum nantinya dilakukan pembangunan di suatu area. Perencanaan pondasi ini harus mempertimbangkan kondisi tanah. Tanah yang berada di suatu area kontruksi bangunan terutama tanah yang ada 
dibawahnya haruslah kuat dalam memikul beban baik beban permukaan maupun beban tanah timbunan dengan tidak mengalami kegagalan geser (Nusantara, 2014). Jenis tanah lempung kurang ideal untuk dilakukan pembangunan langsung diatasnya karena kurangnya faktor keamanan dari lempung (Feld, 2017). Tanah lempung memiliki nilai permeabilitas dan tegangan geser yang rendah, sehingga diperlukan adanya perbaikan terhadap tanah tersebut sebelum nantinya digunakan sebagai landasan dari suatu konstruksi untuk memperoleh daya dukung tanah yang jauh lebih baik (Nusantara, 2014).

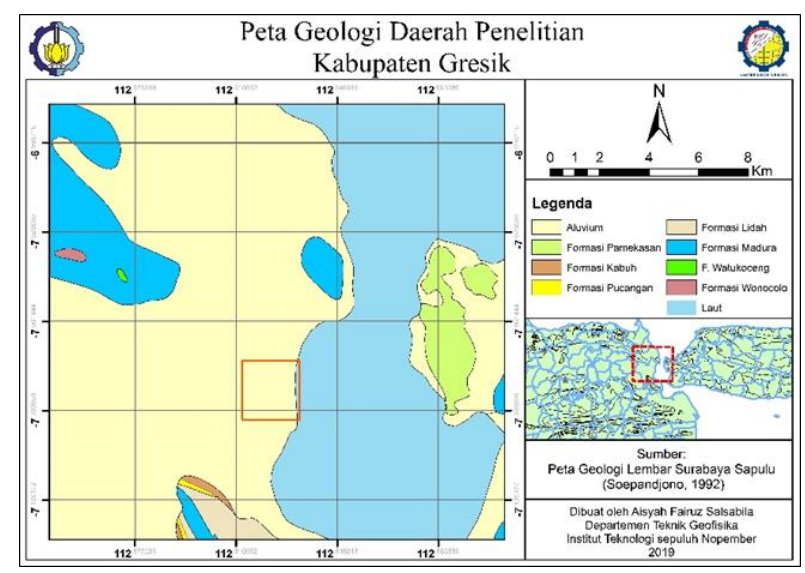

Gambar 1. Peta geologi dan lokasi penelitian

Daya dukung tanah ialah kemampuan tanah untuk menahan tekanan atau beban bangunan yang ada diatas tanah dengan aman dan tidak menimbulkan keruntuhan geser dan penurunan tanah yang berlebih (Nusantara, 2014). Pada tanah lempung, sifat fisis dan mekanis lempung seperti porositas, kuat geser dan kehadiran air akan sangat mempengaruhi kualitas tanahnya. Tanah yang memiliki butir halus terutama tanah lempung akan banyak dipengaruhi oleh air. Karena pada tanah yang memiliki butir halus, luas permukaan spesifiknya akan menjadi lebih besar, dan plastisitas tanahnya akan dipengaruhi oleh variasi kadar air yang ada . Jika lapisan tanah diberikan beban, maka tanah akan mengalami regangan dan penurunan. Penurunan ini dapat terjadi dikarenakan adanya perubahan pada susunan tanah dan juga adanya pengurangan rongga pori/air yang ada di dalam tanah tersebut (H.C. Hardiyatmo, 2018).
Berdasarkan faktor yang dapat mempengaruhi daya dukung tanah tersebut, perlu diketahuinya karakteristik tanah secara fisis sebelum dilakukan pembebanan diatasnya. Sehingga pada penelitian ini dilakukan pengukuran dan analisis parameter fisis lempung. Kemudian digunakan dalam analisis pembebanan guna mengetahui daya dukung tanah lempung dan model timbunan terbaik. Tujuan dilakukannya penelitian ini ialah untuk mendapatkan hubungan parameter fisis tanah lempung dan mengetahui timbunan yang baik berdasarkan nilai daya dukung tananhnya. Pada penelitian ini tidak dilakukan pengukuran untuk mengetahui tinggi muka air tanah dan batas lapisan keras, sehingga nilainya ditetapkan oleh penulis berdasarkan pengamatan di lapangan dengan mengukur tinggi permukaan tanah dari permukaan air laut, hal ini karena lapangan penelitian berada di area pesisir pantai.

\section{Karakter Fisis Tanah}

\section{- Densitas}

Densitas merupakan salah satu karakter fisis batuan. Nilai densitas dapat berubah terhadap perubahan tipe batuan yang diakibatkan adanya mineral, selain itu juga diakibatkan karena nilai porositas yang dimiliki batuan tersebut. Densitas $(\rho)$ merupakan perbandingan massa $(m)$ batuan per satuan unit volume $(V)$ seperti pada persamaan (1).

$$
\rho=\frac{m}{V}
$$

Sedangkan ada beberapa faktor yang mempengaruhi nilai densitas bulk suatu batuan diantaranya komposisi mineral (densitas mineral dan fraksi volume), porositas (pori dan fracture) dan porositas fluida pori batuan (Schon, 2011).

\section{- Porositas}

Porositas $(n)$ didefinisikan sebagai perbandingan antara volume rongga $(V v)$ dengan volume total $(V)$ yang dapat dilihat pada persamaan (2). Nilai porositas dapat dinyatakan dalam bentuk persen ataupun desimal.

$$
n=\frac{V v}{V}
$$


Pada tanah, volume rongga $(V v)$ ialah volume ruang kosong yang terisi oleh fluida (baik air maupun gas)(Hardiyatmo, 2002) (Hardiyatmo, 2002).

\section{- Specific Gravity}

Berat spesifik atau specific gravity tanah (Gs) didefinisikan sebagai perbandingan antara berat volume butiran padat $(\gamma s)$ dengan berat volume air $(\gamma w)$ pada temperatur $4^{\circ} \mathrm{C}$. Gs tidak memiliki dimensi, berat spesifik dari beberapa jenis tanah berkisar antara 2,65 sampai 2,75. Nilai berat spesifik $\mathrm{Gs}=2,67$ sering digunakan untuk tanah-tanah tak berkohesi. Sedangkan untuk tanah kohesif tak organik nilai berat spesifiknya berada diantara 2,68 sampai 2,72 (Hardiyatmo, 2002).

\section{- Kuat Geser Tanah}

Kemampuan tanah untuk melawan tegangan geser yang terjadi pada saat tanah diberikan beban merupakan pengertian dari kuat geser tanah. Hancurnya butir-butir tanah bukan menjadi penyebab terjadinya keruntuhan geser melainkan karena adanya gerakan relatif antar butir-butir tanah tersebut.

$$
S=c+\sigma \tan \varphi
$$

Persamaan (3) merupakan persamaan matematis kuat geser tanah. Dengan :

$\mathrm{S}$ : kekuatan geser tanah

$\mathrm{c}$ : kohesi tanah

$\sigma:$ tegangan normal

$\phi$ : sudut geser dalam tanah (Sijabat, 2010).

Parameter kuat geser tanah diperlukan untuk melakukan analisis kapasitas dukung tanah, stabilitias lereng, dan gaya dorong pada dinding penahan. Berdasarkan teori Mohr (1910) kondisi keruntuhan suatu bahan terjadi diakibatkan karena adanya kombinasi keadaan kritis dari tegangan geser dan tegangan normal.

\section{METODOLOGI}

Penelitian ini dilakukan di kawasan industri Java Integrated Indutrial and Port Estate (JIIPE) di Kecamatan Manyar, Kabupaten Gresik, Jawa Timur. Berdasarkan peta geologi lokasi penelitian berada di daerah pesisir pantai dengan endapan alluvium $(\mathrm{Q} a)$ yang dapat dilihat pada gambar 1. Lokasi pengambilan sampel lempung berada di area reklamasi dengan 12 titik pengambilan sampel yang berjarak $30 \mathrm{~m}$ antar titiknya dengan 4 sampel tanah diambil disetiap titiknya. Area penelitian ini berukuran $100 \times 70 \mathrm{~m}$, dengan kondisi litologi yang cenderung homogen berdasarkan peta geologi, jarak $30 \mathrm{~m}$ dan 12 titik pengambilan sampel sudah cukup untuk mencakup area penelitian. Tahapan metodologi pada penelitian ini dimulai dengan studi literatur, secara lengkap dapat dilihat pada gambar 2.

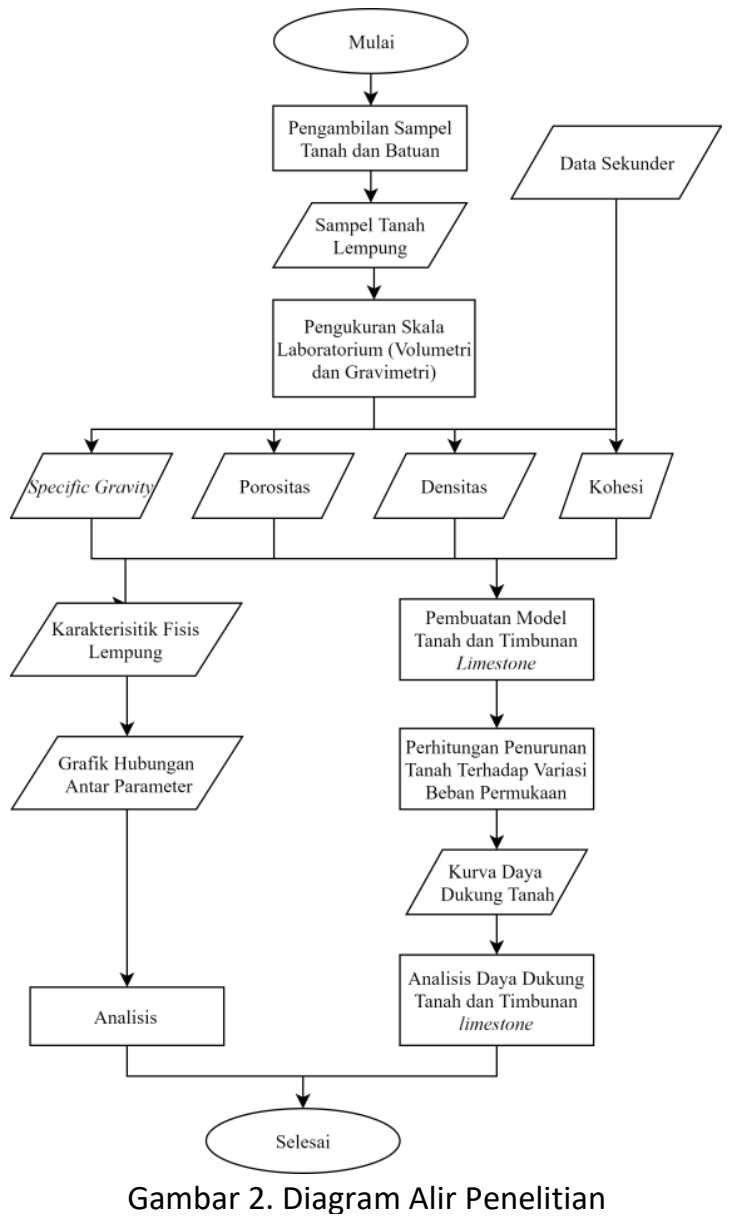

Kemudian dilakukan pengambilan sampel di lapangan. Pengambilan sampel dilakukan setelah menentukan lokasi atau titik pengambilan pada Google Earth, pengambilan sampel dilakukan dengan cara sebagai berikut:

1. Tanah di lokasi digali dengan cangkul sedalam kurang lebih $10-20 \mathrm{~cm}$ untuk mendapatkan sampel tanah asli. Tanah lempung di lokasi pengukuran merupakan lempung urugan yang 
belum ditimbun dengan lapisan limestone. Sehingga lapisan lempung bagian atas sudah mengering karena terkena udara dan sinar matahari. Oleh karena itu diambillah sampel lempung yang masih basah dengan menggalinya sedalam $10-20 \mathrm{~cm}$.

2. Permukaan tanah yang sudah digali diratakan

3. Tabung sampel (tabung PVC) diletakkan tegak lurus diatas permukaan tanah. Kemudian tabung ditekan hingga tenggelam semua. Palu bisa digunakan untuk mendorong tabung hingga sepenuhnya tenggelam

4. Tanah digali untuk diambil tabung sampelnya

5. Kedua sisi tabung diratakan dengan pisau, kemudian ditutup dengan aluminium foil dan kantong plastik agar sampel tetap terjaga keasliaannya. Berikan kode sampel pada tabung dengan menggunakan kertas label

6. Langkah 1-6 diulangi untuk lokasi dan sampel lainnya.

7. Sampel disimpan pada wadah yang telah disediakan.
Setelah sampel lempung didapatkan selanjutnya dilakukan pengukuran volumetri dan gravimetri untuk mendapatkan parameter densitas, porositas dan specific gravity. Parameter inilah yang akan dianalisis hubungannya satu sama lain. Terdapat 12 sampel lempung di lapangan yang kemudian menjadi 24 sampel kecil untuk uji laboratorium. Sehingga data yang didapatkan untuk tiap parameter sebanyak 24 data. Selain itu terdapat juga parameter kohesi yang diperoleh dari data sekunder hasil pengukuran oleh pihak perusahaan yang jumlah datanya juga 24 data, kohesi digunakan juga untuk analisis hubungan antar parameter. Pada pemodelan tanah dan timbunan, digunakan limestone sebagai material timbunan. Kemudian dianalisis seberapa peningkatan daya dukung tanah dengan menggunakan timbunan limestone, digunakan 3 model timbunan dengan tebal limestone yang divariasikan yaitu $2 \mathrm{~m}, 4 \mathrm{~m}$, dan $6 \mathrm{~m}$. Sehingga bisa diketahui model mana yang memiliki daya dukung terbaik.

Tabel 1. Rincian perilaku untuk setiap model

\begin{tabular}{|c|c|c|c|c|c|c|c|c|}
\hline \multirow{2}{*}{ Model } & \multicolumn{8}{|c|}{ Perilaku } \\
\hline & Panjang & $\begin{array}{c}\text { Tebal } \\
\text { lempung }\end{array}$ & $\begin{array}{c}\text { Muka air } \\
\text { tanah }\end{array}$ & $\begin{array}{c}\text { Lapisan } \\
\text { keras }\end{array}$ & $\begin{array}{c}\text { Panjang } \\
\text { beban }\end{array}$ & waktu & $\begin{array}{l}\text { Jumlah } \\
\text { Lapisan }\end{array}$ & Tebal Limestone \\
\hline 1 & \multirow{4}{*}{$140 \mathrm{~m}$} & $20 \mathrm{~m}$ & \multirow{4}{*}{$-4 m$} & \multirow{4}{*}{$-20 m$} & \multirow{4}{*}{$70 m$} & \multirow{4}{*}{365 hari } & 1 & $0 \mathrm{~m}$ \\
\hline 2 & & $16 \mathrm{~m}$ & & & & & 2 & $2 \mathrm{~m}$ \\
\hline 3 & & $16 \mathrm{~m}$ & & & & & 3 & $4 \mathrm{~m}$ \\
\hline 4 & & $16 \mathrm{~m}$ & & & & & 5 & $6 \mathrm{~m}$ \\
\hline
\end{tabular}

Berikut tahapan pemodelan tanah hingga bisa didapatkan nilai daya dukung tanah,

1. Pembuatan model geometri tanah dan timbunan. Pada penelitian ini digunakan 1 model tanah dasar dan 3 model timbunan limestone. Panjang model yang dibuat ialah $140 \mathrm{~m}$. Keterangan lebih rinci untuk setiap model dapat dilihat pada tabel 1 .

2. Input parameter dan jenis tanah yang digunakan pada setiap lapisan. Pada penelitian ini digunakan tanah lempung sebagai tanah dasar, dan untuk tanah timbunan digunakan limestone, pasir, batu (andesit) dan agregat.

3. Penentuan batas muka air tanah dan batas lapisan keras.

4. Perhitungan nilai penuruanan tanah. Pada setiap model diberikan beban $(q)$ dengan nilai yang bervariasi. Kemudian dilakukan iterasi perhitungan, sehingga akan didapatkan nilai penurunan tanah $(U)$ untuk setiap nilai beban yang diberikan.

5.Berdasarkan data beban $(q)$ dan penurunan tanah $(U)$ selanjutnya dibuat kurva daya 
dukung tanah, dengan sumbu-x ialah penurunan tanah $(U)$ dan sumbu-y ialah beban (q).

6. Penentuan nilai daya dukung optimum tanah yang dilihat dari pembelokan kurva daya dukung. Selanjutnya dilakukan analisis dan pembahasan.

\section{HASIL DAN PEMBAHASAN}

\section{Analisis Hubungan Parameter Fisis Lempung}

Berdasarkan hasil pengukuran volumetri dan gravimetri dari 24 sampel tanah, diperoleh rentang nilai masing-masing parameter. Densitas lempung berada pada rentang $1,048-2,020 \mathrm{gr} / \mathrm{cm}^{3}$, dengan rata-rata $1,448 \mathrm{gr} / \mathrm{cm}^{3}$. Porositas didapatkan rentang nilai dari $62,468-80,994 \%$ dan rata-rata nilainya ialah $70,046 \%$. Rentang nilai Specific gravity yang didapatkan ialah dari 2,231-3,651, dengan rata-rata 2,565. Kemudian untuk kohesi didapatkan dari 24 data sekunder yang berupa data borehole, diperoleh nilai pada rentang $1,96-12,16 \mathrm{kN} / \mathrm{m}^{2}$ dan rata-rata nilainya ialah $5,238 \mathrm{kN} / \mathrm{m}^{2}$. Dari data parameter yang didapatkan tersebut, kemudian dibuat crossplot hubungan antar parameter dan dilakukan regresi linier sederhana guna memperoleh persamaan linier, sehingga dapat dianalisis hubungan antara parameter satu dengan parameter lainnya. Hasil dari analisis regresi dapat memberikan gambaran untuk membuat keputusan apakah perubahan nilai variabel dependen dapat melalui peningkatan variabel independen atau tidak (Sugiyono, 2006). Crossplot dari hubungan antar parameter disajikan pada gambar 3.

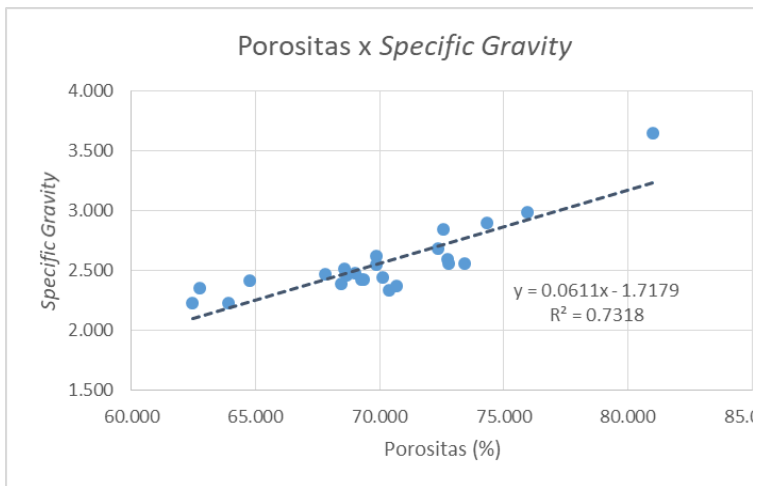

(a)

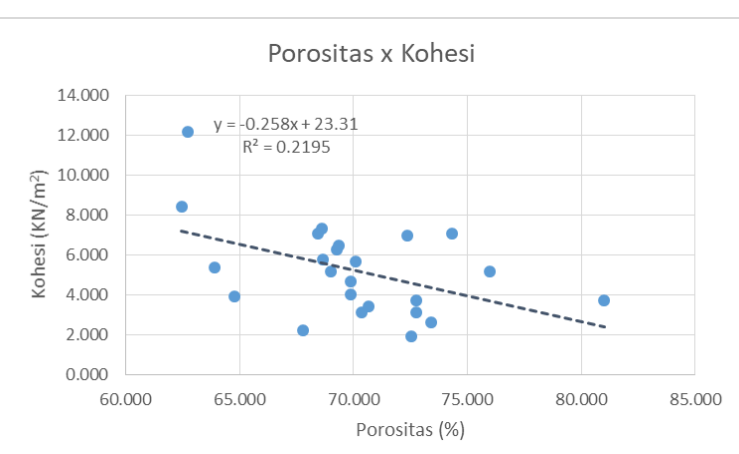

(b)

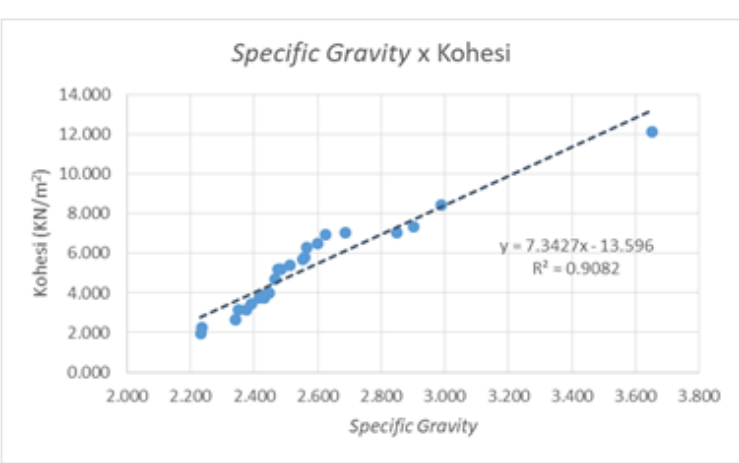

(c)

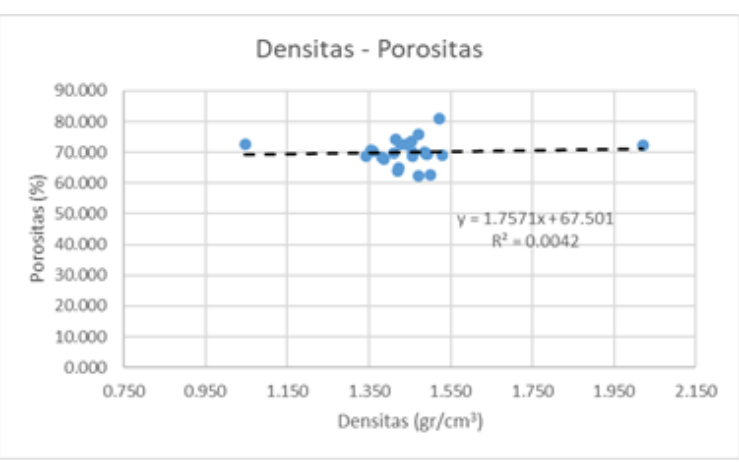

(d)

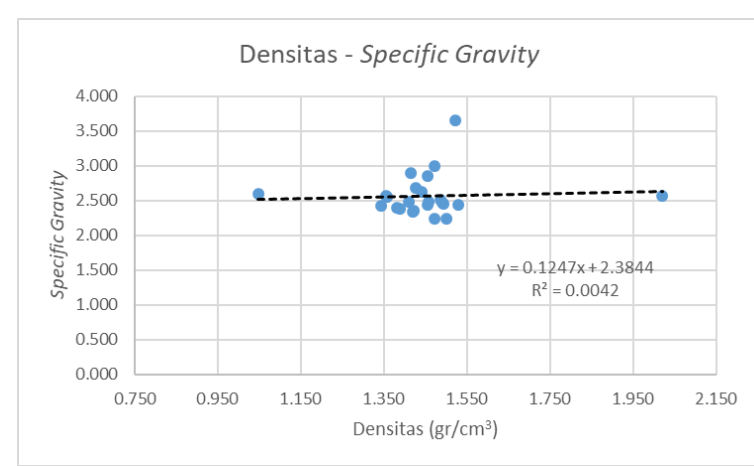

(e) 


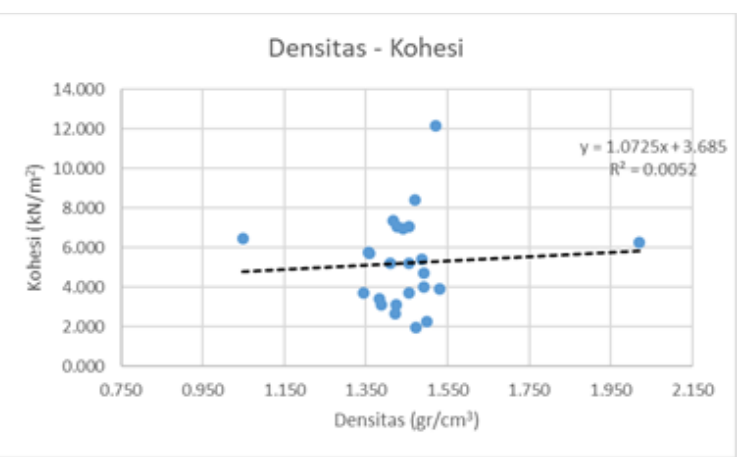

(f)

Gambar 3. (a) Crossplot hubungan Porositas dan Specific Gravity, (b) Crossplot hubungan Porositas dan kohesi, (c) Crossplot hubungan Specific Gravity dan kohesi, (d) Crossplot hubungan Densitas dan Porositas, (e) Crossplot hubungan Densitas dan Specific Gravity, (f) Crossplot hubungan Densitas dan kohesi

Berdasarkan hasil crossplot hubungan antar parameter kemudian dianalisis untuk mengetahui seberapa berpengaruh perubahan suatu parameter terhadap parameter lainnya. Hasil yang didapatkan disajikan dalam tabel 2.

Tabel 2. Hasil Hubungan Antar Parameter Fisis Lempung

\begin{tabular}{|c|c|c|c|}
\hline Hubungan & Persamaan & $\begin{array}{c}\text { Koefisien } \\
\text { Determinasi } \\
\left(\mathrm{R}^{2}\right)\end{array}$ & Keterangan \\
\hline $\begin{array}{c}\text { Porositas - } \\
\text { Specific } \\
\text { Gravity }\end{array}$ & $\begin{array}{c}\mathrm{Gs}=0,0611 \\
\varphi-1,7179\end{array}$ & 0,7318 & $\begin{array}{c}\text { Berbanding } \\
\text { lurus }\end{array}$ \\
\hline $\begin{array}{c}\text { Porositas- } \\
\text { Kohesi }\end{array}$ & $\begin{array}{c}\mathrm{c}=-0,258 \varphi \\
-23,31\end{array}$ & 0,2195 & $\begin{array}{c}\text { Berbanding } \\
\text { terbalik }\end{array}$ \\
\hline $\begin{array}{c}\text { Specific } \\
\text { Gravity- } \\
\text { Kohesi }\end{array}$ & $\begin{array}{c}\mathrm{c}=7,3427 \\
\mathrm{Gs}-13,596\end{array}$ & 0,9082 & $\begin{array}{c}\text { Berbanding } \\
\text { lurus }\end{array}$ \\
\hline $\begin{array}{c}\text { Densitas- } \\
\text { Porositas }\end{array}$ & $\begin{array}{c}\varphi=1,757 \rho \\
+67,501\end{array}$ & 0,0042 & $\begin{array}{c}\text { Korelasi } \\
\text { rendah / } \\
\text { buruk }\end{array}$ \\
\hline $\begin{array}{c}\text { Densitas - } \\
\text { Specific } \\
\text { Gravity }\end{array}$ & $\begin{array}{c}\mathrm{Gs}=0,1247 \\
\rho+2,384\end{array}$ & 0,0042 & $\begin{array}{c}\text { Korelasi } \\
\text { rendah / } \\
\text { buruk }\end{array}$ \\
\hline $\begin{array}{c}\text { Densitas - } \\
\text { Kohesi }\end{array}$ & $\mathrm{c}=1,0725 \rho$ \\
$+3,685$ & 0,0052 & $\begin{array}{c}\text { Korelasi } \\
\text { rendah / } \\
\text { buruk }\end{array}$ \\
\hline
\end{tabular}

Dari nilai koefisien determinasi dan bentuk kurva hubungan, dapat disimpulkan bahwa hanya terdapat 3 hubungan yang memiliki korelasi baik yakni ketika nilai $R^{2}$ hampir mendekati 1 , dan lebih dari 0,1 . Sedangkan untuk hubungan yang memiliki nilai $R^{2}$ yang rendah $(<0,1)$ dianggap memiliki korelasi yang buruk. Artinya ketika nilai parameter $\mathrm{X}$ berubah maka nilai parameter $Y$ belum tentu berubah, karena parameter $X$ hanya sedikit mempengaruhi perubahan paremeter $Y$. Terdapat parameter lain yang lebih berpengaruh terhadap perubahan parameter $\mathrm{Y}$.

\section{Analisis Daya Dukung Optimum Tanah}

Pada analisis ini digunakan 4 buah model tanah sesuai dengan tabel 1 . Kemudian dilakukan pembebanan dan diamati nilai daya dukung tanahnya. Parameter masukan yang digunakan pada software di penelitian ini disajikan dalam tabel 3. Data limestone didapatkan dari penelitian (Putra, 2018) yang dilakukan di lapangan yang sama dengan jenis limestone yang sama digunakan untuk tanah timbunan pada penelitian ini dan nilai koefisien permeabilitas dari peneitian (Ishibashi dan Hazarika, 2015).

Tabel 3. Data tanah yang digunakan

\begin{tabular}{|c|c|c|}
\hline Parameter & Lempung & Limestone \\
\hline Unit Weight $(\gamma)\left(\mathrm{kN} / \mathrm{m}^{3}\right)$ & 14,2 & 18,838 \\
\hline $\begin{array}{c}\text { Koefisien Permeabilitas (k) } \\
\text { (m/hari) }\end{array}$ & $9,00 \times 10^{-5}$ & $5,16 \times 10^{-6}$ \\
\hline $\begin{array}{l}\text { Modulus Elatisitas (E) } \\
\left(\mathrm{kN} / \mathrm{m}^{2}\right)\end{array}$ & 1723,538 & 6965,536 \\
\hline Poisson's Ratio $(\mu)$ & 0,4 & 0,24 \\
\hline Kohesi (c) (kN/m²) & 5,238 & 5,129 \\
\hline Sudut gesek dalam $(\varphi)$ & 6 & 44 \\
\hline
\end{tabular}

\section{- Model 1}

Model 1 untuk penelitian ini ialah model tanah dasar yaitu tanah lempung saja dengan ketebalan 20 $m$, sesuai dengan gambar 4 (a). Nilai beban diberikan secara bervariasi sehingga didapatkan nilai penurunan tanah. Selanjutnya dibuat kurva daya dukung tanah dengan nilai beban sebagai sumbu-y dan nilai penurunan tanah sebagai sumbu-x. Kurva daya dukung untuk model 1 dapat dilihat pada gambar 4 (b). Nilai penurunan tanah untuk setiap beban disajikan dalam tabel 4 . 


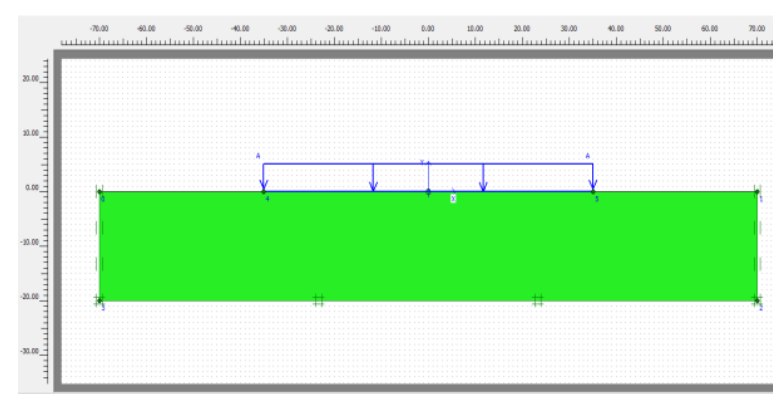

(a)

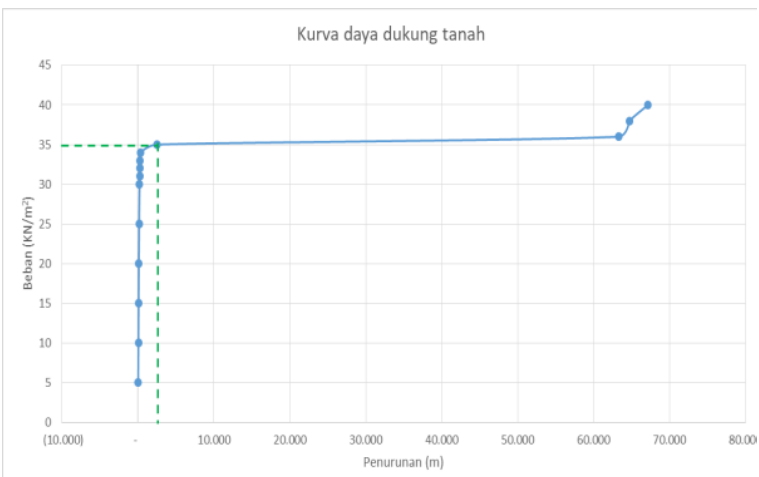

(b)

Gambar 4. (a) Penampang model 1 (lapisan lempung),

Tabel 4. Nilai penurunan tanah terhadap beban pada model 1

\begin{tabular}{|c|c|}
\hline Penurunan $(\mathrm{m})$ & Beban $\mathrm{q}\left(\mathrm{kN} / \mathrm{m}^{2}\right)$ \\
\hline 0,031 & 5 \\
\hline 0,061 & 10 \\
\hline 0,092 & 15 \\
\hline 0,123 & 20 \\
\hline 0,156 & 25 \\
\hline 0,216 & 30 \\
\hline 0,233 & 31 \\
\hline 0,254 & 32 \\
\hline 0,280 & 33 \\
\hline 0,324 & 34 \\
\hline 0,407 & 35 \\
\hline 67,980 & 36 \\
\hline 71,710 & 38 \\
\hline 69,390 & 40 \\
\hline
\end{tabular}

Berdasarkan kurva daya dukung tanah, dapat dilihat bahwa kurva awalnya berupa garis lurus linier yang kemudian berbelok. Titik pembelokan ini merupakan batas daya dukung optimum tanah. Sehingga pada model 1 yang berupa tanah dasar lempung memiliki daya dukung optimum sebesar 35 $\mathrm{kN} / \mathrm{m}^{2}$.

\section{- $\quad$ Model 2}

Dimensi dari model 2 dapat dilihat pada gambar 5 (a). Kurva daya dukung untuk model 2 dapat dilihat pada gambar 5 (b). Nilai penurunan tanah untuk setiap beban disajikan dalam tabel 5 .

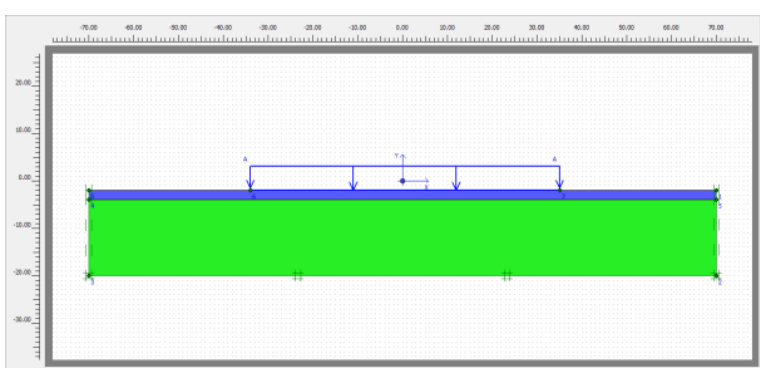

(a)

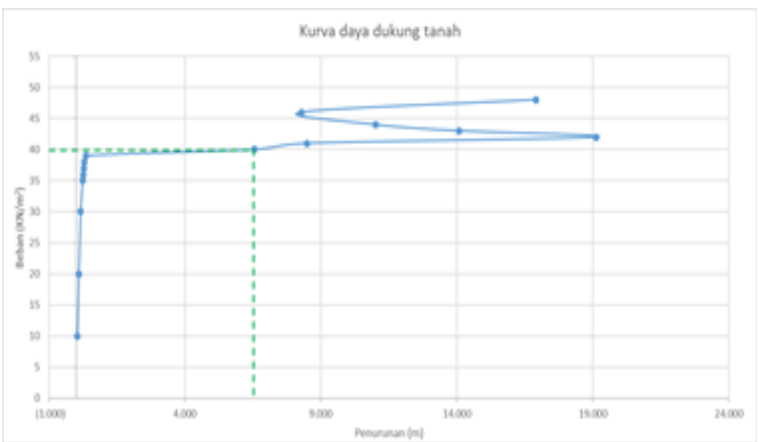

(b)

Gambar 5. (a) Penampang model 2 (lapisan lempung dan limestone $2 \mathrm{~m}$ ), (b) Kurva daya dukung tanah model 2 
Tabel 5. Nilai penurunan tanah terhadap beban pada model 2

\begin{tabular}{|c|c|}
\hline Penurunan $(\mathrm{m})$ & Beban $\mathrm{q}\left(\mathrm{kN} / \mathrm{m}^{2}\right)$ \\
\hline 0,051 & 10 \\
\hline 0,102 & 20 \\
\hline 0,170 & 30 \\
\hline 0,239 & 35 \\
\hline 0,256 & 36 \\
\hline 0,278 & 37 \\
\hline 0,308 & 38 \\
\hline 0,364 & 39 \\
\hline 6,560 & 40 \\
\hline 8,480 & 41 \\
\hline 19,110 & 42 \\
\hline 14,080 & 43 \\
\hline 11,010 & 44 \\
\hline 8,290 & 46 \\
\hline 16,900 & 48 \\
\hline
\end{tabular}

Berdasarkan kurva daya dukung tanah, model 2 yang berupa tanah dasar lempung dengan timbunan limestone $2 \mathrm{~m}$ memiliki daya dukung optimum sebesar $40 \mathrm{kN} / \mathrm{m}^{2}$.

\section{- Model 3}

Model 3 memiliki dimensi yang sama dengan model 2, model 3 bisa dilihat pada gambar 6 (a). Model 3 tersusun atas tanah dasar lempung setebal $16 \mathrm{~m}$ dan timbunan limestone setebal $4 \mathrm{~m}$. Kurva daya dukung untuk model 3 dapat dilihat pada gambar 6 (b). Nilai penurunan tanah untuk setiap beban disajikan dalam tabel 6 .

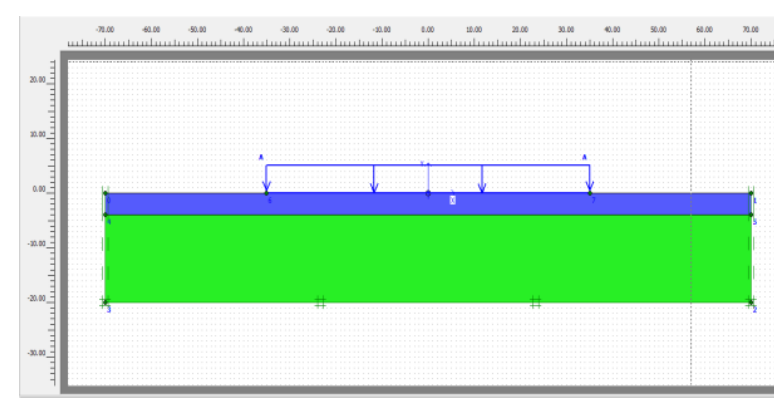

(a)

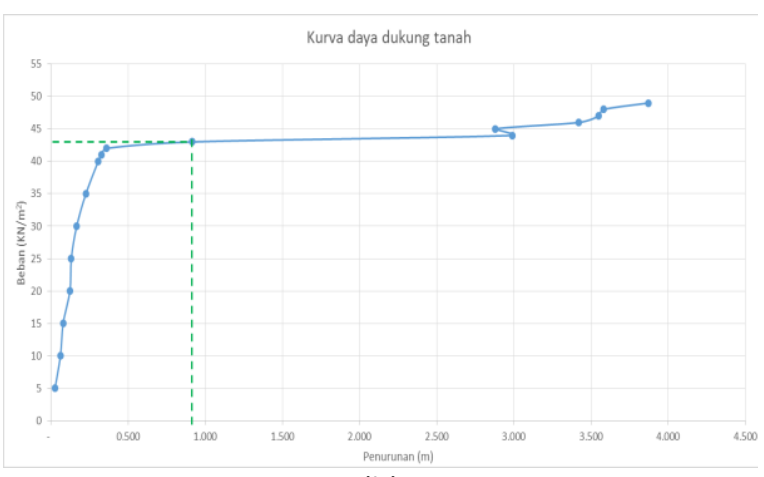

(b)

Gambar 6. (a) Penampang model 3 (lapisan lempung dan limestone $4 \mathrm{~m}$ ), (b) Kurva daya dukung tanah model 3

Berdasarkan kurva daya dukung tanah, model 3 yang berupa tanah dasar lempung dengan timbunan limestone $4 \mathrm{~m}$ memiliki daya dukung optimum sebesar $43 \mathrm{kN} / \mathrm{m}^{2}$.

Tabel 6. Nilai penurunan tanah terhadap beban pada model 3

\begin{tabular}{|c|c|}
\hline Penurunan $(\mathrm{m})$ & Beban q $\left(\mathrm{kN} / \mathrm{m}^{2}\right)$ \\
\hline 0,026 & 5 \\
\hline 0,061 & 10 \\
\hline 0,079 & 15 \\
\hline 0,123 & 20 \\
\hline 0,132 & 25 \\
\hline 0,167 & 30 \\
\hline 0,227 & 35 \\
\hline 0,307 & 40 \\
\hline 0,328 & 41 \\
\hline 0,358 & 42 \\
\hline 0,916 & 43 \\
\hline 2,990 & 44 \\
\hline 2,880 & 45 \\
\hline 3,420 & 46 \\
\hline 3,550 & 47 \\
\hline 3,580 & 48 \\
\hline 3,870 & 49 \\
\hline 2,950 & 50 \\
\hline & \\
\hline & \\
\hline & \\
\hline & 490 \\
\hline
\end{tabular}

\section{- $\quad$ Model 4}

Model 4 terdiri dari lapisan lempung setebal 16 $\mathrm{m}$ dan timbunan limestone $6 \mathrm{~m}$. Bentuk modelnya seperti pada gambar 7 (a). Kurva daya dukung untuk model 4 dapat dilihat pada gambar 7 (b). Nilai penurunan tanah untuk setiap beban disajikan dalam tabel 7 . 


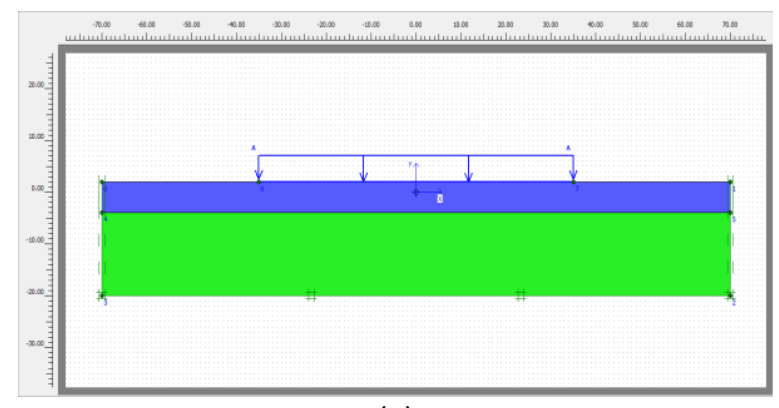

(a)

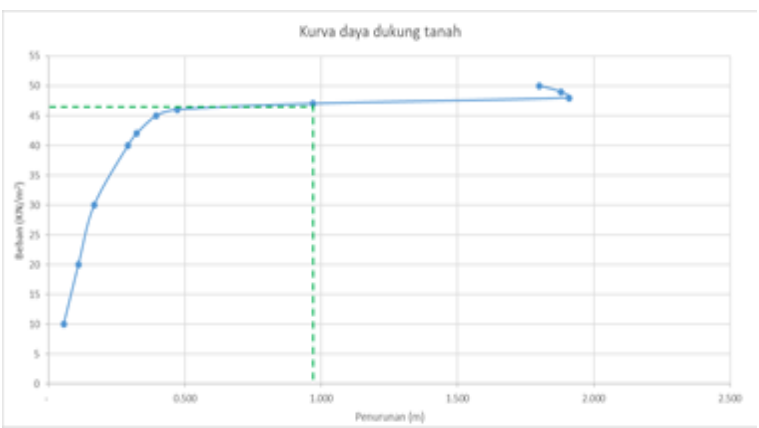

(b)

Gambar 7. (a) Penampang model 4 (lapisan lempung dan limestone $6 \mathrm{~m}$ ), (b) Kurva daya dukung tanah model 4

Tabel 7. Nilai penurunan tanah terhadap beban pada model 4

\begin{tabular}{|c|c|}
\hline $\begin{array}{c}\text { Penurunan } \\
(\mathrm{m})\end{array}$ & $\begin{array}{c}\text { Beban } \mathrm{q} \\
\left(\mathrm{kN} / \mathrm{m}^{2}\right)\end{array}$ \\
\hline 0,055 & 10 \\
\hline 0,109 & 20 \\
\hline 0,167 & 30 \\
\hline 0,291 & 40 \\
\hline 0,323 & 42 \\
\hline 0,395 & 45 \\
\hline 0,471 & 46 \\
\hline 0,970 & 47 \\
\hline 1,910 & 48 \\
\hline 1,880 & 49 \\
\hline 1,800 & 50 \\
\hline
\end{tabular}

Berdasarkan kurva daya dukung tanah, model 4 yang berupa tanah dasar lempung dengan timbunan limestone $6 \mathrm{~m}$ memiliki daya dukung optimum sebesar $47 \mathrm{kN} / \mathrm{m}^{2}$.

\section{PENUTUP}

\section{Simpulan}

Dari penelitian yang telah dilakukan, didapatkan kesimpulan bahwa:

1. Berdasarkan nilai parameter fisis yang didapatkan yakni densitas, porositas, specific gravity dan kohesi, didapatkan bahwa lempung yang ada daerah penelitian tergolong lempung yang sangat lunak dan memiliki potensi untuk jenuh air karena memiliki porositas ditas $60 \%$.

2. Hubungan antar parameter yang diteliti didapatkan bahwa specific gravity, porositas, dan kohesi memiliki korelasi yang baik, yang artinya nilai dari parameter tersebut saling berpengaruh satu sama lain.

3. Parameter densitas memiliki korelasi yang buruk dengan parameter specific gravity, porositas, dan kohesi. Artinya perubahan nilai densitas tidak mempengaruhi nilai parameter yang lain, begitupun sebaliknya.

4. Berdasarkan model tanah dan timbunan, didapatkan peningkatan nilai daya dukung ketika tanah dasar lempung diberikan timbunan limestone. Model yang memiliki daya dukung terbaik ialah model 4 dengan tebal timbunan limestone setebal $6 \mathrm{~m}$. Daya dukung tanahnya sebesar $47 \mathrm{kN} / \mathrm{m}^{2}$.

\section{Saran}

Saran dari penelitian ini adalah:

1. Jumlah sampel pengukuran perlu diperbanyak sehingga distribusi data yang didapat lebih jelas dan lebih baik yang akan berpengaruh pada analisis sebaran nilai dan analisis hubungan parameter

2. Melakukan penelitian untuk mendapatkan kondisi riil di lapangan penelitian, seperti penelitian untuk mendapatkan kondisi muka air tanah dan batas lapisan keras.

3. Kedepannya bisa melakukan variasi nilai parameter pada analisis pemodelan, guna mengetahui pengaruh parameter tersebut terhadap daya dukung tanah.

4. Melakukan penelitian lebih jauh terkait litologi daerah penelitian dengan menggunakan metode geofisika lainnya untuk mengetahui 
adanya litologi lain dibawah lapisan lempung sehingga dapat diketahui pengaruh adanya lapisan keras (bedrock) terhadap daya dukung tanah.

\section{Ucapan Terima Kasih}

Ucapan terima kasih penulis sampaikan kepada PT. BKMS (Berkah Kawasan Manyar Sejahtera) yang telah memberikan izin kepada penulis untuk melakukan penelitian di kawasan JIIPE.

\section{DAFTAR PUSTAKA}

Feld, J. (2017), The Factor of Safety in Soil and Rock Mechanics, hal. 14.

Hardiyatmo, H.C. (2002), Mekanika Tanah I. Yogyakarta, Gadjah Mada University Press.

H.C. Hardiyatmo (2018), Mekanika Tanah 2 Edisi Keenam, UGM Press. Diambil dari https://ugmpress.ugm.ac.id/en/product/sainsteknologi/mekanika-tanah-2-edisi-keenam.

Ishibashi, I. dan Hazarika, H. (2015), Soil Mechanics Fundamentals and Applications, 2 Ed., Publisher of Humanities, Social Science \& STEM Books. Diambil dari https://www.routledge.com/SoilMechanics-Fundamentals-and-

Applications/IshibashiHazarika/p/book/9781482250411.

Nusantara, M.A. (2014), Analisa Daya Dukung Pondasi Dangkal pada Tanah Lempung Menggunakan Perkuatan Anyaman Bambu dan Grid Bambu dengan Bantuan Program Plaxis, Journal:eArticle, Sriwijaya University. Diambil dari

https://www.neliti.com/publications/212100/a nalisa-daya-dukung-pondasi-dangkal-padatanah-lempung-menggunakan-perkuatan-any.

Putra, M.H.R. (2018), Analisis Sifat Fisi Batuan Karbonat Untuk Evaluasi Bahan Timbunan Institut Teknologi Sepuluh Nopember,.

Schon, J.H. (2011), Physical Properties of Rocks HANDBOOK OF PETROLEUM EXPLORATION AND PRODUCTION, Diambil dari https://www.academia.edu/9805929/Physical_ Properties_of_Rocks_HANDBOOK_OF_PETROLE UM_EXPLORATION_AND_PRODUCTION.

Sijabat, D.M.F. (2010), ANALISA PERKUATAN DAYA DUKUNG TANAH LUNAK DENGAN GEOSINTETIK MENGGUNAKAN PEMODELAN PERANGKAT LUNAK (PROGRAM PLAXIS), hal. 133.

Sugiyono (2006), Statistika Untuk Penelitian, 10 Ed., CV ALFABETA, Bandung.
Sukardi (1992), Peta geologi lembar Surabaya \& Sapulu, Jawa = Geological map of the Surabaya \& Sapulu quadrangle, Jawa. 